Contents List available at RAZI Publishing journal-of-geology-pjg/

\title{
Diagenesis of Miocene Sandstone in the District Sudunhoti and Poonch, Azad Jammu and Kashmir, Pakistan
}

\author{
Muhammad Yasin* \\ Visiting lecturer, Institute of Geology, University of Azad Jammu and Kashmir, Muzaffarabad, Pakistan \\ ${ }^{*}$ Corresponding Author email: Rajayasinkhan@gmail.com
}

This is an open access article distributed under the Creative Commons Attribution License, which permits unrestricted use, distribution, and reproduction in any medium, provided the original work is properly cited

\section{ARTICLE DETAILS}

\section{Article history:}

Received 24 October 2016 Accepted 7 December 2016 Available online 3 January 2017

\section{Keywords:}

Petrography, Epoxy resin, Alizarin-red, Potassium ferrocyanide, Tape-compassclinometer, Stylolitization

\section{ABSTRACT}

The petrographic analysis of Miocene sandstone at latitude $33^{\circ} 45^{\prime} 00^{\prime \prime} \mathrm{N}$ to $33^{\circ} 51^{\prime} 30^{\prime \prime} \mathrm{N}$ and Longitude $73^{\circ} 35^{\prime} 36^{\prime \prime} \mathrm{E}$ to $73^{\circ} 45^{\prime} 00^{\prime \prime} \mathrm{E}$ in the Himalayan fold and thrust belt was based on field observations and study of representative samples. At least 30 rock samples dislodged from outcrops for thin section preparations were soaked in blue epoxy resin before thin section grinding, then etched and stained using alizarin-red and potassium ferrocyanide for carbonate identification. The stratigraphic sections in the area were measured by tape-compass-clinometer method. Petrographic and textural data revealed that the quartz, feldspar, rock fragments, accessories, matrix and cement form the bulk composition of the rocks. The Miocene sandstones are lithic arenites and lithic greywackes. Further interpretation revealed the fracturing, flexure grain deformations, dissolutions, stylolitization, clay minerals anthogenesis, calcite and silica cementation during the diagenetic history of rocks.

\section{Introduction}

The region occupies a broad area at latitude $33^{\circ} 45^{\prime} 00^{\prime \prime} \mathrm{N}$ to $33^{\circ} 51^{\prime} 30^{\prime \prime} \mathrm{N}$ and Longitude $73^{\circ} 35^{\prime} 36^{\prime \prime} \mathrm{E}$ to $73^{\circ} 45^{\prime} 00^{\prime \prime} \mathrm{E}$ (Fig. 1) in the southeastern part of Hazara Kashmir Syntaxes (HKS) in the Himalayan fold and thrust belt. The area is bounded between Himalayan Frontal Thrust (HFT) and the Main Boundary Thrust (MBT) toward its southern and northern extremities (Kazmi \& Rana, 1982). The Miocene sandstone of the area varies in color from light green to dark gray and weathered black. In addition, the sandstone is medium to coarse grained, thick bedded to massive, sheared and fractured (Yasin, 2014). Moreover, the sandstone is interbedded with shale, clays, siltstone and mudstone. Furthermore, the conglomerates (Fig. 2E), invertebrate fossils (Fig. 2F) and wood fossils are embedded in sandstone in a few regions. However, the sandstone exhibits sedimentary structures including ripple laminations, planner bedding, carbonate concretions, pebble imbrications rip ups and groove marks (Yasin, 2014). The interbedded siltstone is thick bedded, jointed and alternates with shale (Fig. 1). The shales are calcareous, fissile, thin bedded, possess carbonate concretions and yields leaf imprints (Yasin, 2014). The clays have variegated colors (red, maroon, brown, light gray and black). The quartzite, volcanic, granite, granite gneisses, marble, dolomite, phyllite, granite gneiss and intraformational siltstone are the conglomerate particles tessellated in the sandstone (Yasin, 2014; Sorby, 1863).

\section{Previous work}

Only a few studies of the area exist. Earlier workers including carried out reconnaissance surveys of the recondite places, desolate valleys and the arduous ascents of mountains (Wadia, 1982; Meddlicot, 1876; Lydekker, 1876; Middlemiss, 1896; Chaudhary \& Ashraf, 1980). However, the area remained uncharted and the geotechnical properties of the sandstone (Yasin, 2014; Akhter et al., 2015).

\section{Materials and Methods}

At least 30 rock samples were dislodged from the outcrops. The rock samples were prepared by cutting and grinding in the Geoscience Laboratory, Islamabad, Pakistan. The samples were soaked with blue epoxy resin before thin-section grinding. Thin sections were etched and stained using alizarin-red and potassium ferrocyanide for carbonate identification (Lindholm \& Finkelman, 1972). The thin sections of the rocks were studied and the mineral contents were identified under petrographic microscope. The percentage of mineral grains under microscope was determined by visual acuity in Muzaffarabad, Pakistan. The rocks were classified on the basis of mineralogy and matrix following the classification scheme (Blatt \& Tracy, 1996). The Miocene sandstone rocks of the area were classified as lithic arenites and lithic greywackes (Yasin, 2014). The study of minerals and cement were helpful in understand the diagenetic history of the rocks. The lithology of Miocene sediments was also prepared by using tape-compass-clinometers methods in the field following the similar techniques (Compton,1985). A classic example is shown in Fig. 1.

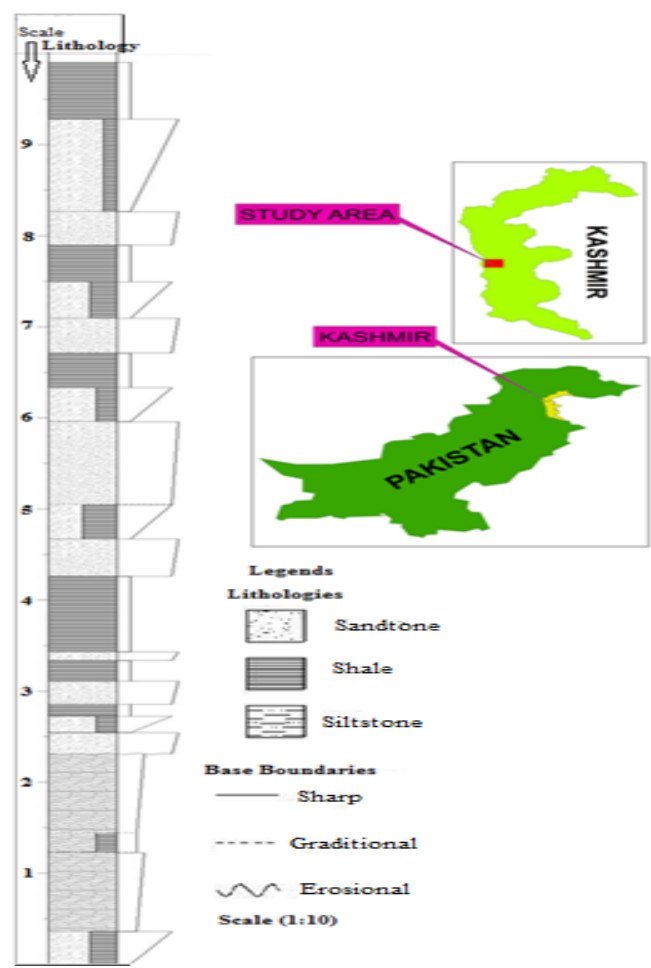


Fig.1. A measured section of the project area. The study area is shown towards right hand corner of the diagram. The study area lies in District Sudunhoti and Poonch, Azad Kashmir, Pakistan.

Table 1: Local stratigraphy of the study area, established by earlier workers.

\begin{tabular}{|c|c|c|}
\hline Formation & Age & Description \\
\hline $\begin{array}{l}\text { Alluvial } \\
\text { Terraces }\end{array}$ & Recent & $\begin{array}{l}\text { Unconsolidated deposits of clay, silt, } \\
\text { gravel. }\end{array}$ \\
\hline ……........... & $\begin{array}{l}\text { Unconformit } \\
y\end{array}$ & 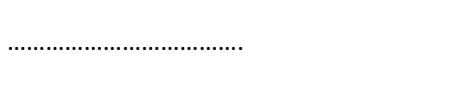 \\
\hline $\begin{array}{l}\text { Dhok } \\
\text { Pathan } \\
\text { Formation }\end{array}$ & $\begin{array}{l}\text { Late } \\
\text { Miocene }\end{array}$ & $\begin{array}{l}\text { Gray, fine to medium grained, medium } \\
\text { to thick bedded sandstone with clay and } \\
\text { siltstone. Sandstone } 60 \% \text { and clays } 40 \% \text {. }\end{array}$ \\
\hline $\begin{array}{l}\text { Nagri } \\
\text { Formation }\end{array}$ & $\begin{array}{l}\text { Late } \\
\text { Miocene }\end{array}$ & $\begin{array}{l}\text { Greenish gray to light gray, massive, } \\
\text { medium to coarse gained sandstone, } \\
\text { siltstone and mudstone. The sandstone } \\
\text { alternate with clays. It includes } 40 \% \\
\text { clays and } 60 \% \text { sandstone. }\end{array}$ \\
\hline$\ldots \ldots \ldots \ldots$ & Fault & 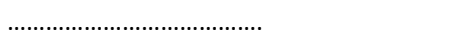 \\
\hline $\begin{array}{l}\text { Murree } \\
\text { Formation }\end{array}$ & $\begin{array}{l}\text { Early } \\
\text { Miocene }\end{array}$ & $\begin{array}{l}\text { Clays, shales and sandstone. Sandstone } \\
\text { is fine to medium grained. }\end{array}$ \\
\hline
\end{tabular}

\section{Results}

The petrography of Miocene sandstone rock samples indicate that the quartz including monocrystalline (Fig. 2B; Fig. 2C), polycrystalline (Fig. 2L), stretched and elongated, undulatory (Fig. $2 \mathrm{~N}$ ) and non undulatory, feldspar (albite, perthite, microperthite, perthite and orthoclase), rock fragments having igneous (Fig. 2B), metamorphic and sedimentary origin, accessories including biotite, muscovite (Fig. 2G, 2H \& 2l), chlorite, hornblende, hematite, tourmaline and zircon, the cementing material like calcite (Fig. 2B), silica (Fig. $2 \mathrm{~J}$ ) and the matrix (sericite, clays; Fig. 2K \& 2M) coexist in the rock (Yasin, 2014). The modal analysis of the rocks was used to unravel the diagenesis of the rock. The diagenetic process during deep burial involves compaction, cementation, and clay mineral authigenesis. The compaction in rock samples includes both physical compaction (Fig. 2G; $2 \mathrm{H} \& 2 \mathrm{I}$ ) and chemical compaction (Fig. $2 \mathrm{~A} \& 2 \mathrm{~N}$ ), the cementation includes both silica (Fig. 2J) and calcite (Fig. 2B). However, the detrital minerals grains are deformed and resulted in clay mineral authigenesis (Fig. $2 \mathrm{k} \& 2 \mathrm{M}$ ).

\section{Discussions}

The material derived from Himalayan orogeny was continuously deposited in rapidly subsiding foreland basin (Bossart \& Ottiger, 1989). The deposition and burial of sediments resulted in physical and chemical change, transforming loose, unconsolidated material into hard and compact lithified rocks. During compaction and lithification, the pore spaces in sandstone are reduced (Boggs, 2006). The cement is precipitated between pore spaces. The framework grains are strongly held together by cement.

The compaction of sands involves rearrangement of grains, fractures in quartz (Fig. 2C), ductile deformation of rock fragments, dissolution of quartz (Fig. 2A \& 2N) and other grains (Imam \&Shaw, 1985). The porosity and permeability are reduced by compaction of ductile rock fragments such as schists and muscovite (Fig. 2G; $2 \mathrm{H} \& 2 \mathrm{I}$ ). The flexure grain deformation is revealed by bending of mica (Fig. 2G) during diagenesis (Boggs, 2006).

The solubility of grain at contact usually increases under stress during a process called pressure solution or chemical compaction. The dissolution of grain under lithotomic stress is an important criterion for the recognition of rock deformation (Mimran, 1975; Mimran, 1977, Alvarez et al., 1976). The pressure solution in the rocks was categorized into the intergranular and stylolitization Fig. 2D (Sorby, 1863; Bates \& Jackson, 1980). The process commonly reinforced by compaction reduces porosity and also forms quartz cement (Rittenhouse, 1971; Manus \& Coogan 1974; Mitra \& Beard, 1980). The pressure solution develops concavo-convex or sutured contacts on the confronting sides (Fig. 2A \& 2N) of the quartz grains (Taylor, 1950). Temperature also promotes pressure solution during compaction
(Houseknecht, 1984). The grains are easily deformed at high temperature. The polycrystalline quartz grains are easily deformed by pressure solution than the monocrystalline quartz (Fig. 2L).

The calcite (Fig. 2B) is the dominant type of cement precipitated between pore spaces of lit arenites and greywacke during lithification. The formation of calcite cement is favored by higher concentration of calcium carbonate in pore water. Apart from calcite, minor amount of silica also acts as cementing material in rock samples. The silica content in sandstone increases with decrease in matrix content. Some rocks have chalcedony cement (Fig. 2J). The chalcedony has "plumose texture". The radiating bundles of quartz are visible in chalcedony. The silica is precipitated at low temperature when pore water is supersaturated with respect to silica. Minor amount of chart is precipitated between pore spaces of sandstone (Yasin, 2014).

The Authigenic clays are formed by the decomposition of feldspar (Fig. 2K) and other mica minerals (Fig. $2 \mathrm{M}$ ) in sandstone. These are developed in the sediments shortly after deposition or during burial or diagenesis.
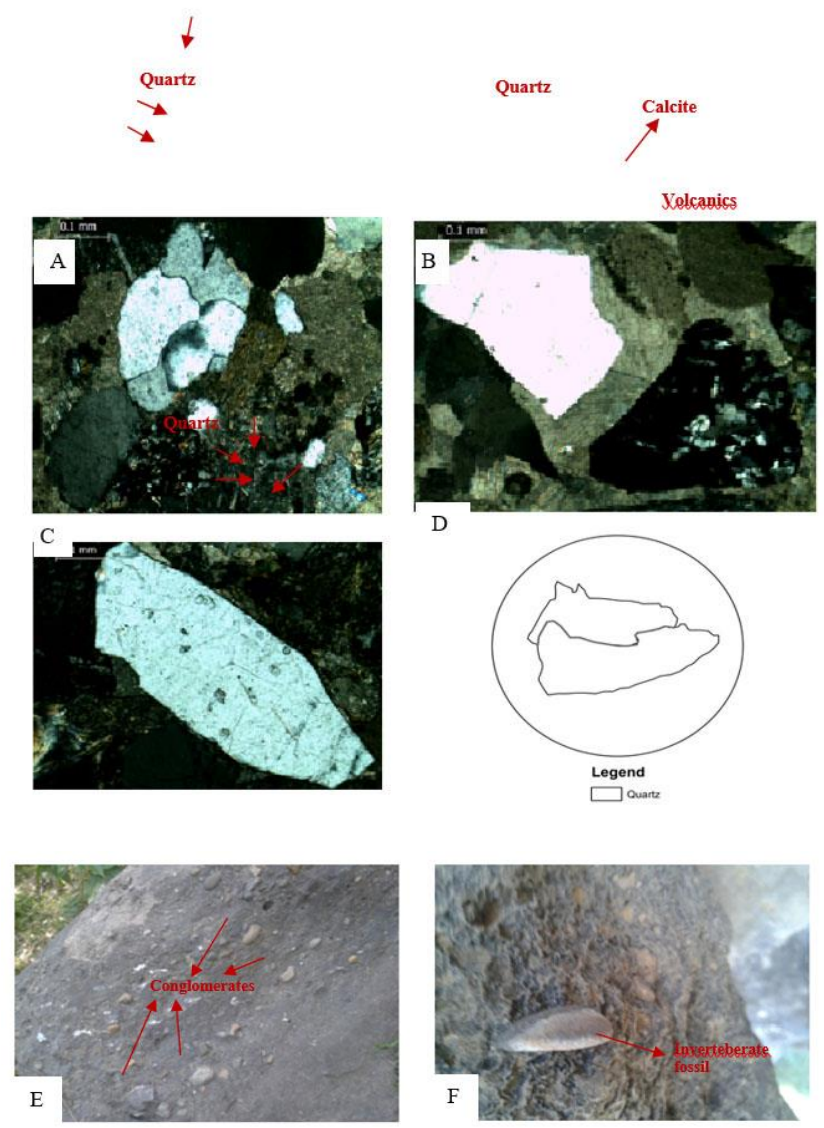

D
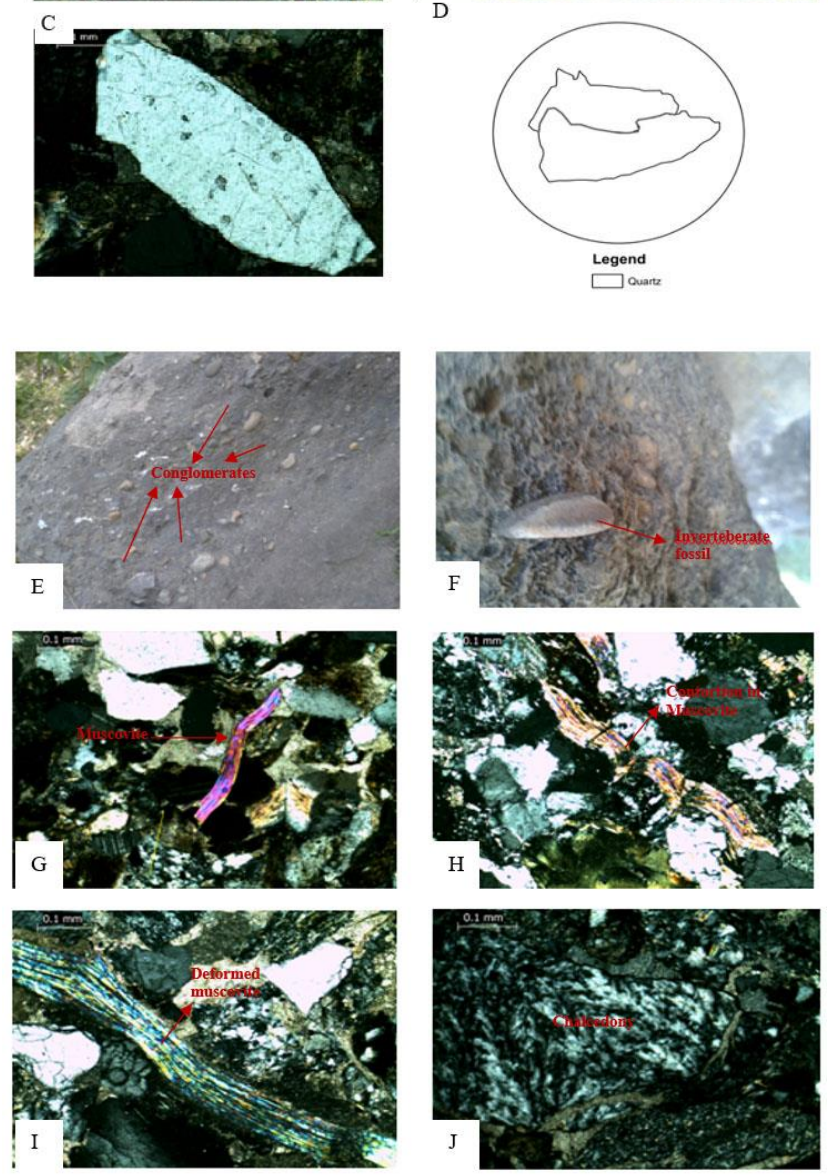

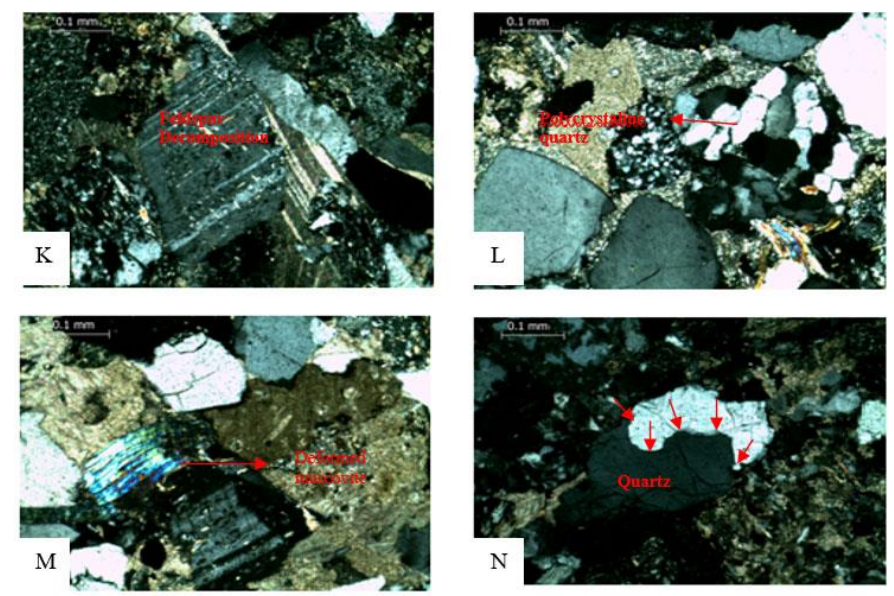

Fig. 2. Photomicrographs of Miocene sandstone showing (A) suturing of quartz grain (indicated by arrows) resulting from chemical compaction or pressure solution, (B) quartz and volcanic rock fragments in calcite cement, (C) microfractures in quartz grains (indicated by arrows) (D) a sketch of quartz grain (not according to scale) illustrating stylolitic texture in quartz grain, (E) Field photograph indicating tesselated conglomerates in Miocene sandstone, (F) Field photograph showing invertebrate fossil in sandstone, (G), (H), (I) Photomicrographs showing flexure grain deformations (contortions) in muscovite, $(\mathrm{J})$ plumose texture formed by quartz fibers in chalcedony, $(\mathrm{K})$ decomposition of feldspar (clay mineral authigenesis, (L) suturing in polycrystalline quartz, (M) sericitization in mica, (N) Strong undulatory extinction and chemical compaction in quartz (indicated by arrows).

\section{Conclusions:}

The study area lies in the southeastern part of Hazara Kashmir syntaxes in the Himalayan fold and thrust belt. The thick cover sequence of sedimentary rocks ranging from Miocene to Recent age was formed during Tertiary Himalayan orogeny. The ripple laminations, planner bedding, carbonate concretions, pebble imbrications rip ups, groove mark and wood fossils in the Miocene sandstone indicates a fluviatile environment of deposition in front of rising Himalayas. The modal mineralogical data of the sandstone shows that the sandstones are lithic arenite and lithic greywacke. The compaction of rocks during diagenesis resulted in fracturing of quartz, ductile deformations of lithic fragments, flexure grain deformations of muscovite, dissolution and stylolitization (commonly identified by concave convex or sinusoidal contacts on the confronting sides of the mineral quartz). The diagenetic process further involved in the cementation of calcite in the void spaces. Minor amount of chalcedony and pore filling chart were also precipitated in the pores of the rock. Anthogenesis of clays however, resulted from the decomposition of feldspar and mica minerals (criticization).

\section{Acknowledgements:}

The author is highly thankful to the University of Azad Jammu and Kashmir, Muzaffarabad, Pakistan for transport facility and the Director Geoscience Laboratory, Dr. Rana Asif for providing facility of thin section preparation at Geoscience Laboratory, Islamabad, Pakistan.

\section{References}

[1] Akhter, Q. J., Xue. C., Lap. T. T., Aiying, W., and Ghaffar, A., (2015) Miocene sandstone of Murree Formation, Rawalakot, Azad Kashmir, Pakistan: Geotechnical properties evaluation of Geo-material. International Journal of Research in Engineering \& Technology, 3(3): 51-60.

[2] Alvarez, W., Engelder, T., Lowrie, W., (1976). Formation of spaced cleavage and folds in limestone by dissolution. Geology, 4: 698-701.

[3] Bates, R. L., Jackson, J. A., (1980). Glossary of Geology. Falls Church, VA: American Geological Institute, 749: ISBN 10: 0913312150 ISBN 13: 9780913312155.

[4] Blatt, H., Tracy, R. (1996). Petrology, Igneous, Sedimentary and Metamorphic. $2^{\text {nd }}$ end., W. H. Freeman Pub. New York, 497 pp.
[5] Boggs, S., (2006). Principles of Sedimentology and Stratigraphy. 4rth ed., J. Univ. Oregon. Pearson education, Inc, NJ. 662 pp.

[6] Bossart, P., Ottiger, R., (1989). Rocks of the Murree Formation in northern Pakistan: Indicators of a descending foreland basin of late Paleocene to middle Eocene age. Eclogae Geologicae Helvetiae, 82(1): 133-165.

[7] Chaudhary, M. N., Ashraf, M., (1980). The volcanic rocks of Poonch district, Azad Kashmir. Special Issue, Geology Bulletin University Peshawar, 131(152): 121-128.

[8] Compton, R., (1985). Geology in the field. John Wiley and Son., New York. 398 pp.

[9] Houseknecht, D.W., (1984). Influence of grain size and temperature on intergranular pressure solution, quartz cementation, and porosity in quartzes sandstone: Sediment. Journal of Sedimentary Petrology, 54(2): 03480361.

Imam, M.B., Shaw, H.E., (1985). The diagenesis of Neogene clastic sediments from the Bengal Basin, Bangladesh. Journal of Sedimentary Petrology, 55(5): 665-671.

[10] Kazmi, A. H., Rana, R. A., (1982). Tectonic map of Pakistan. Geological Survey of Pakistan, Scale 1:2000000.

[11] Lindholm, R.C., Finkelman, R.B., (1972). Calcite staining: semi quantitative determination of ferrous iron: Noted. Journal of Sedimentary Petrology, 42(1): 239-245.

[12] Lydekker, R., (1876). Notes on geology of the Pir Panjal and neighbouring Districts. Geological Survey India Recruitment, 9(2): 155-162.

[13] Manus, R. W., Coogan, A.H., (1974). Bulk volume reduction and pressure-solution derived cement. Journal of Sedimentary Petrology, 44(2): 466-471.

[14] Meddlicot, H. B., (1876). Notes on the sub-Himalayan series of Jammu Hills. Recruitment Geology Survey of India, 9: 49 pp.

[15] Middlemiss, C. S., (1896). The geology of Hazara and black mountains. Geology Survey India Membership, 26: 302 pp.

[16] Mimran, Y., (1975). Fabric deformation induced in the cretaceous chalks by tectonic stresses. Tectonophysics, 26(3-4): 309-316.

[17] Mimran, Y., (1977). Chalk deformation and large scale migration of calcium carbonate. Sedimentology, 24(3): 333-360.

[18] Mitra, S., Beard, W. C., (1980). Theoretical models of porosity reduction by pressure solution for well sorted sandstones. Journal of Sedimentary of Petrology, 50(4): 1347-1360.

[19] Rittenhouse, G., (1971). Pore-space reduction by solution and cementation. Bulletin American Association of Petroleum Geologists, 55(1): 80-91.

[20] Sorby, H. C., (1863). On the direct correlation of mechanical and chemical forces. Proceeding of the Royal Society of London, 12(1862-1863): 583-550.

[21] Taylor, J. M., (1950). Pore space reduction in sandstones. Bulletin American Association of Petroleum Geologists,

34(4): 701-716.

[22] Yasin, M., (2014). Petrography and Sedimentology of Neogene sediments in Mang and adjoining areas in the Sub Himalayas, Azad Jammu and Kashmir, Pakistan, Unpublished MS Thesis, University of Azad Jammu and Kashmir, Muzaffarabad, pp. 213.

[23] Wadia, D. N., (1928). The geology of the Poonch state (Kashmir) and adjacent portions of the Punjab. Geological Survey of India, 51(2): 185370 . 